\title{
Development of Electrical CAR Learning Media as A Future Alternative CAR
}

\author{
Supari Muslim ${ }^{1)}$, Tri Wrahatnolo ${ }^{2)}$, Sri Handayani ${ }^{3)}$, Erina Rahmadyanti ${ }^{4)}$, Nita Kusumawati ${ }^{5)}$, Achmad \\ Imam Agung ${ }^{6)}$ \\ ${ }^{1)}$ Universitas Negeri Surabaya, Surabaya, Indonesia \\ E-mail: supari@unesa.ac.id \\ ${ }^{2)}$ Universitas Negeri Surabaya, Surabaya, Indonesia \\ E-mail:triwrahatnolo@unesa.ac.id \\ ${ }^{3)}$ Universitas Negeri Surabaya, Surabaya, Indonesia \\ E-mail: srihandajani@unesa.ac.id \\ ${ }^{4)}$ Universitas Negeri Surabaya, Surabaya, Indonesia \\ E-mail: erinarahmadyanti@unesa.ac.id \\ ${ }^{5)}$ Universitas Negeri Surabaya, Surabaya, Indonesia \\ E-mail: nitakusumawati@unesa.ac.id \\ ${ }^{6)}$ Universitas Malang, Surabaya, Indonesia \\ E-mail:achmadimam@unesa.ac.id
}

\begin{abstract}
This research aims to: (1) develop Electric Car Learning Media through research and development (R\&D) ADDIE Model (Analysis, Design, Development, Implementation, and Evaluation); (2) knowing the level of feasibility of learning media for electric cars (LMEC) in a learning perspective; and (3) to determine the effectiveness of LMEC in the learning process. The study found that: (1) based on the validator's assessment, that the LMEC that had been developed was very suitable for use in learning Electric Cars; (2) based on student assessment, that LMEC is very suitable for use in learning Electric Cars in the Department of Electrical Engineering, State University of Surabaya; and (3) LMEC is very effective, proven as many as $24(77.41 \%)$ of students get a score of learning outcomes in the range $71-100$, with good and excellent categories.
\end{abstract}

Keywords: Learning Media; Electric Cars; Development

\section{INTRODUCTION}

Vocational education is secondary education that prepares students to work in certain fields (National Education System Law No.20 of 2003. These goals can be achieved through the 2013 SMK curriculum by referring to (1) eight National Education Standards which include content standards, process standards, graduate competency standards, teacher and education staff standards, facilities and infrastructure standards, management standards, financing standards, and standards educational assessment; and (2) an effort, so that the abundant productive age human resources (around $70 \%$ of the Indonesian population), can be transformed into human resources who have competence and skills through education, so as not to become a burden of development in the future. Therefore, vocational education including Vocational High 
Schools (SMK) was chosen by UNESCO and the ILO as an integral part of "Technical and Vocational Education and Training (TVET)" within the "Education for All" framework (Sudira, 2018) Considering the importance of vocational education in Indonesia, Presidential Instruction No. 9 of 2016 has been issued, on the revitalization of vocational education which includes: (1) making a road map for developing vocational schools; (2) perfecting and aligning the SMK curriculum with competencies according to user needs; (3) increasing the number and competence of teaching and education personnel in vocational high schools; (4) increasing cooperation with Ministries/Institutions, Regional Governments, and the business/industrial world; (5) increasing access to SMK graduates' certification and SMK accreditation; and (6) forming vocational development working groups.

With the revitalization program, the learning design in vocational high schools needs to be adjusted to the competencies needed by the business world and industry. Therefore, improving the quality of teachers and education personnel, as well as providing infrastructure, including learning media, is an important part of the vocational education revitalization program at Vocational Education Revitalization Paper. Vocational learning must be effective to prepare vocational graduates to be ready to work and ready to try (Sudira, 2018). In addition to the effectiveness factor, the aspect of school transition to the world of work is an important aspect that must be considered in vocational learning in the XXI century (Sudira, 2018a), because it becomes an important task for the lecturers of the Educational Personnel Institute whose job is to prepare vocational teacher candidates. The question that can be asked is: "how should a learning media be developed" so that the learning process in the lecture room can run effectively and efficiently. For this reason, a research entitled "Development of Learning Media for Electric Cars as an Alternative Car of the Future" should be carried out.

The research needs to be done, with the premise that learning media is an important part of an overall learning process. Media comes from the word medium, which means something that is designed, to reach many users, including students in the learning process. Media is a communication channel that carries messages with instructional purposes (Omadara \& Adu, 2014). In line with this opinion, Akhtar \& Ali (2012) view that the media is a means to send messages from a learning perspective. Media is a tool that can be used as a vehicle for channeling learning information or channeling messages to achieve learning objectives (Djamarah \& Aswan, 2002). In the context of media as a source of learning, then the media can broadly be interpreted as a tool/means of communication including humans, objects, or events that enable students to gain knowledge and skills. Thus it can be concluded that: (1) the media is a container of messages that the channel wants to forward to the target/recipient of the message; and (2) that the material to be conveyed is a learning message, and the goal to be achieved is the occurrence of the learning process to obtain the desired learning outcomes.
Based on the understanding of the media as described above, in essence, the learning process is a process of communication or delivery of messages from the introduction to the recipient. The message in the form of subject matter is poured into communication symbols both verbal (words and writing) and nonverbal. This message will be captured by students as knowledge, skills, and values that can be used in everyday life. For the message to be conveyed effectively, adequate facilities/media are needed. Student retention or capture power is strongly influenced by the model of learning activities undertaken by the teacher. According to Eyler and Giles (1999), students can only absorb 5\% of the learning material if the teacher's activities in learning are done with lectures, and if learning is done by reading the students' absorbency increases to $10 \%$ (check Figure 1). Whereas if the learning activity is done by "doing" the student's retention power reaches 90\%. Research by Eyler and Giles (1999) proves that the effectiveness of learning is influenced by the media used by the teacher. They found that the learning model that is located at the top of the cone, namely learning that only involves verbal symbols through text presentation, is the learning that produces the highest level of abstraction. In contrast, the most effective learning is learning that is at the base of the cone, i.e., students are directly involved with the learning experience according to instructional objectives. The level of abstraction in this learning model is very low, making it easier for students to absorb new knowledge and skills following the learning objectives.

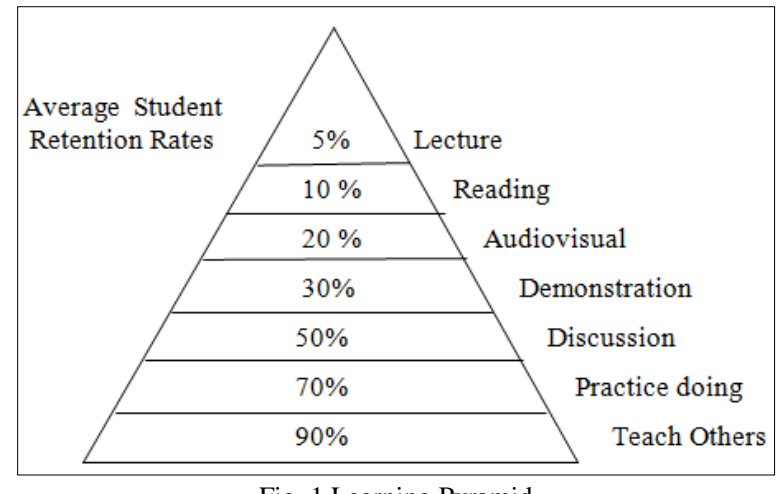

Fig. 1 Learning Pyramid

(Source: Eyler \& Giles, 1999)

The benefits of the media in the learning process are to facilitate interactions between teachers and students so that learning activities will be more effective and efficient. According to Kemp \& Dayton (Depdiknas, 2003), that the benefits of instructional media are: (1) delivery of subject matter can be uninformed; (2) the learning process becomes clearer and more interesting; (3) the learning process becomes more interactive; (4) efficiency in time and energy; (5) improving the quality of student learning outcomes; (6) the media allows the learning process to be carried out anywhere and at any time; (7) the media can foster positive student attitudes towards the material and learning process; and (8) changing the teacher's role in a more positive and productive direction. Learning media can fulfill three main functions if 
the media is used for individuals, groups, or a large listener group (Kemp \& Dayton, 1985), namely: (1) motivating interests and actions, (2) presenting information, and (3) giving instructions. The expected outcome is to generate interest and stimulate students or listeners to act. Achieving this goal will affect attitudes, values, and emotions. Taking into account the benefits of instructional media as described above, the materials used to support this research "Development of Electric Car Learning Media as an Alternative Car of the Future" include the following:

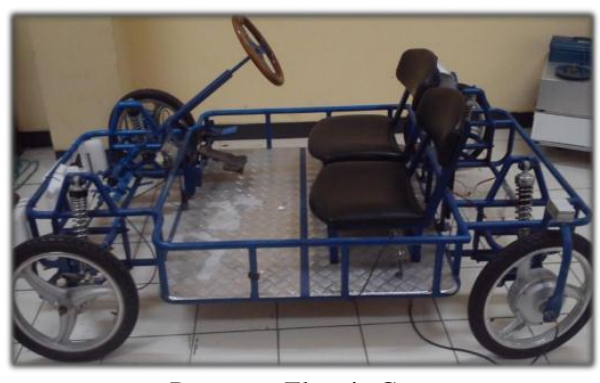

a. Prototype Electric Car

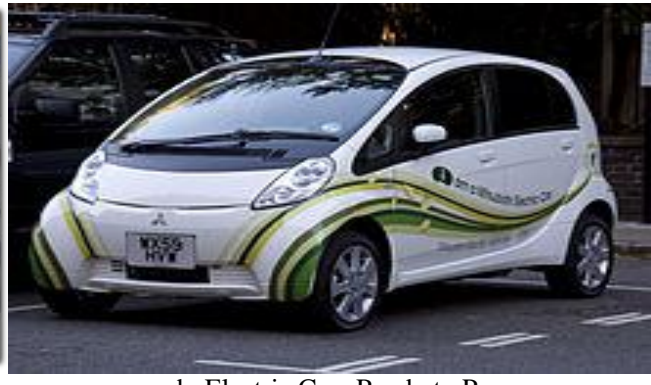

b. Electric Cars Ready to Pave

Fig. 2 Electric Cars

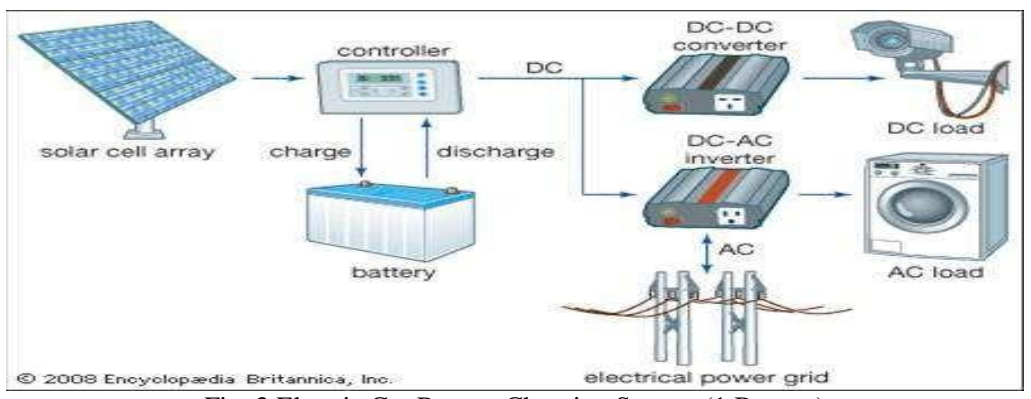

Fig. 3 Electric Car Battery Charging System (1 Battery)

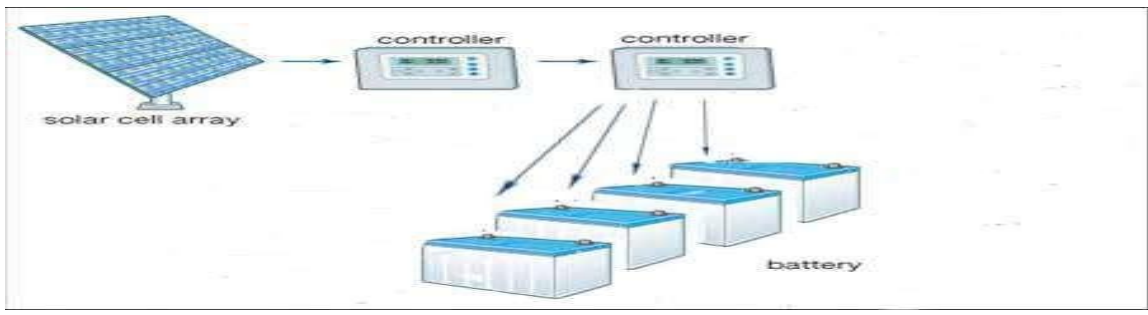

Fig. 4 Electric Car Battery Filling System (4 Battery)

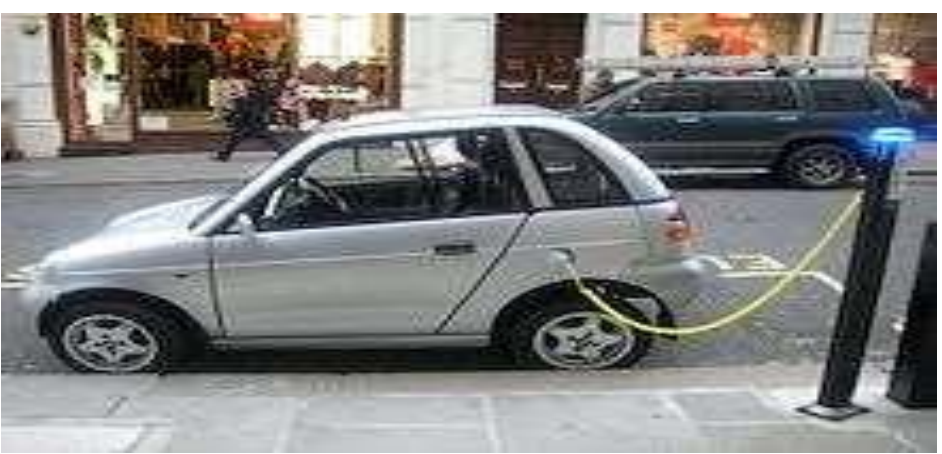

Fig. 5 Electric Reva/G-Wiz I Car Charging a Battery at an Electric Charging Station (Roadside City of London) 


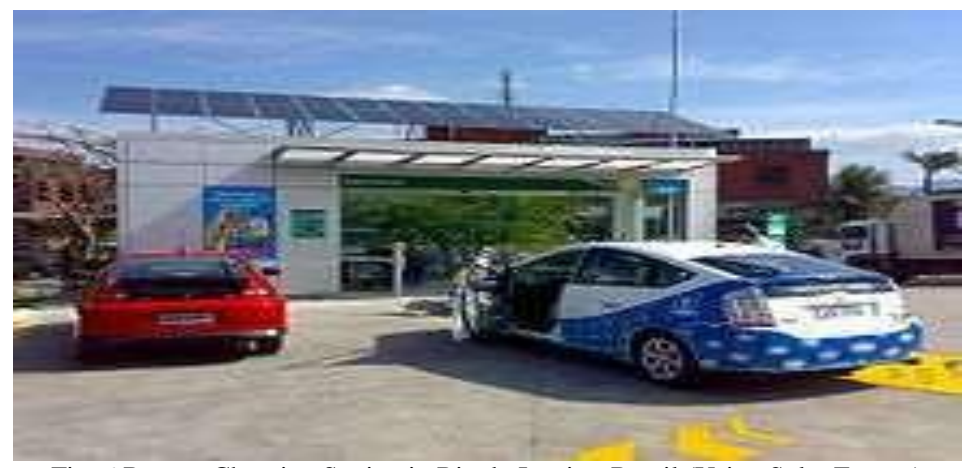

Fig. 6 Battery Charging Station in Rio de Janeiro, Brazil (Using Solar Energy)

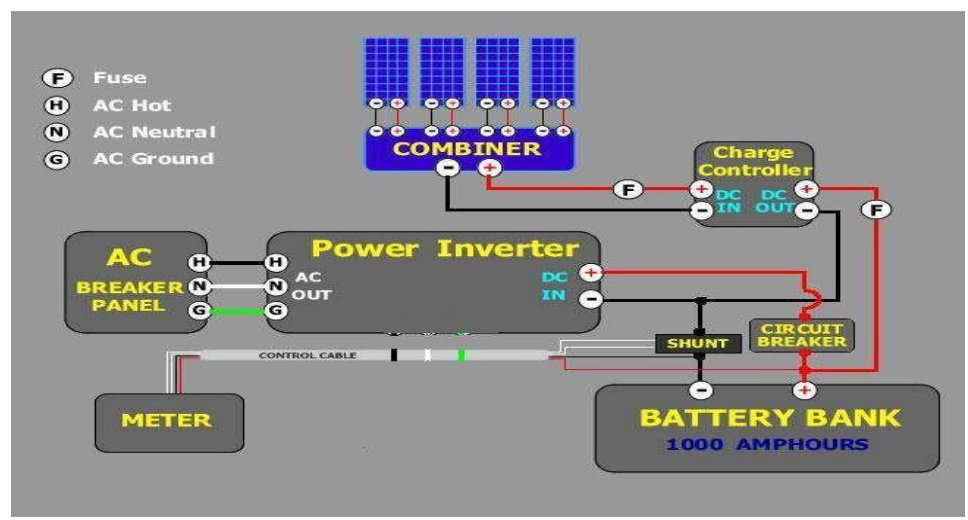

Fig. 7 Schematic for charging the battery with electricity from solar cells

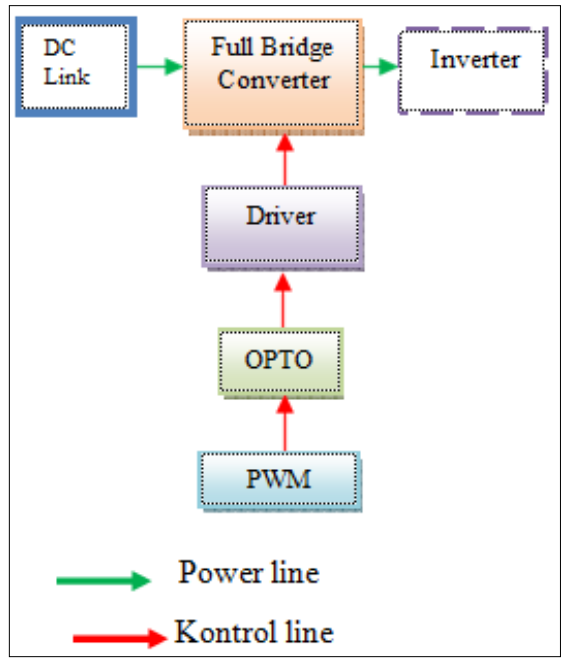

Fig. 8 Full-Bridge Converter and 3 Phase Inverter as Drive an Electric Car Based on a Microcontroller 


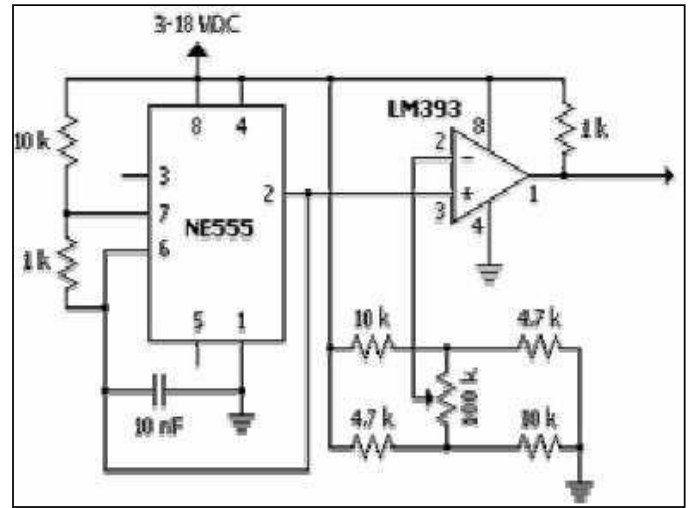

Fig. 9 Analog PWM circuit

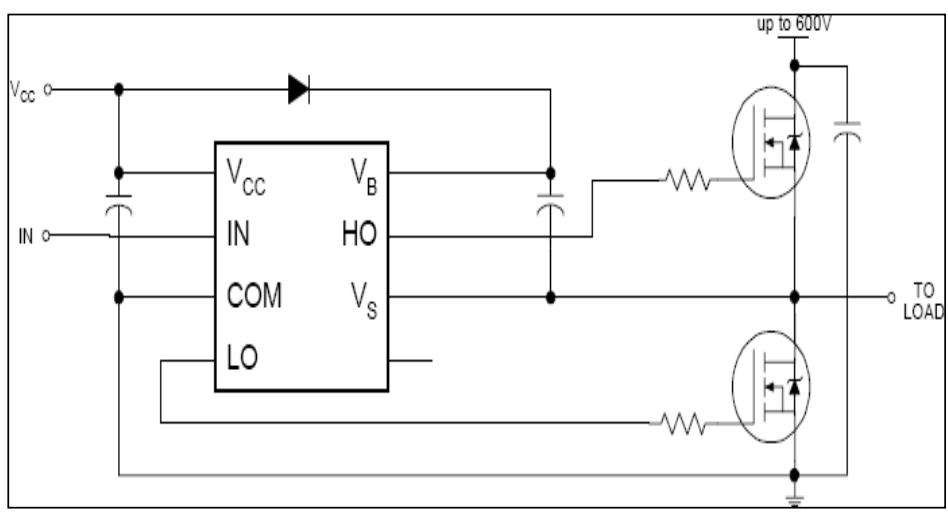

Fig. 10 IR2111 driver IC circuit

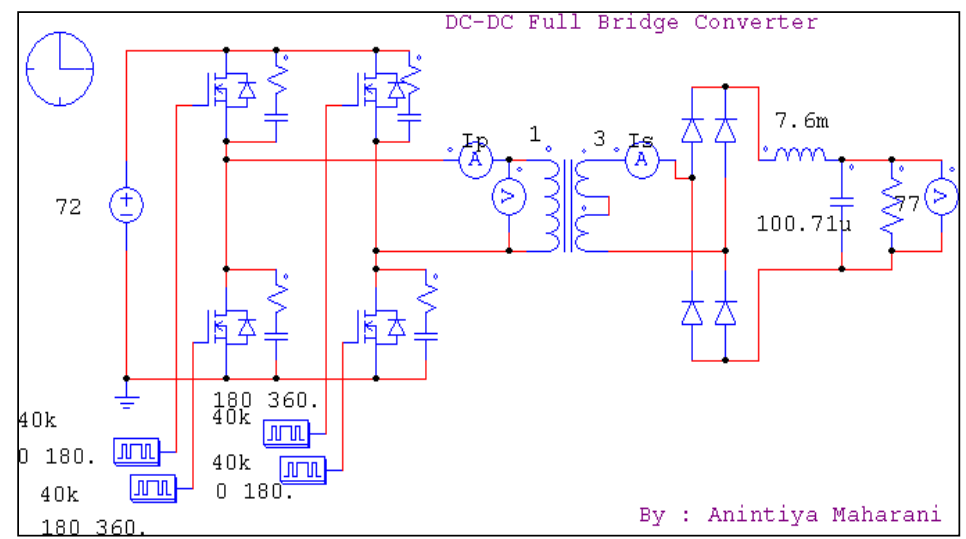

Fig. 11 Full-Bridge Converter Series 


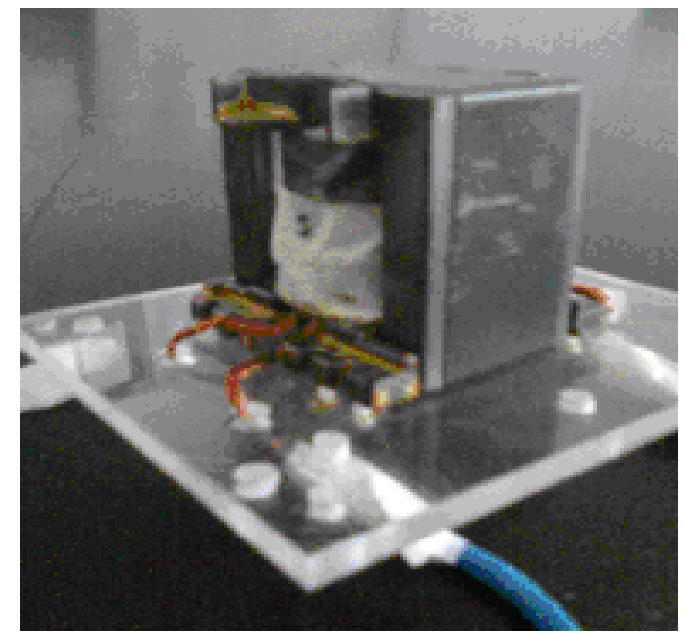

Fig. 12 High-Frequency Transformer

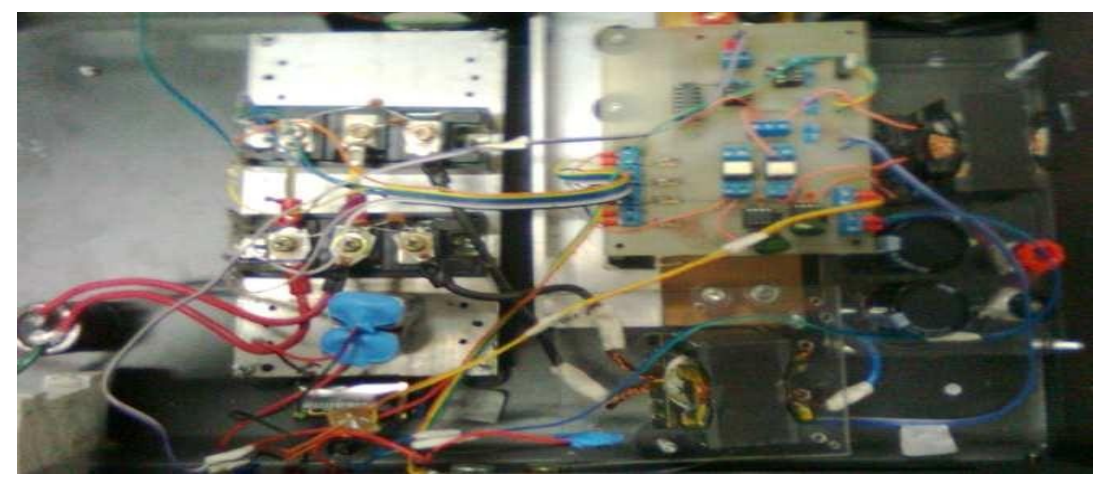

Fig. 13 Full-Bridge Converter Series

There are several research results related to learning media. Muslim, Suprianto, and Gitama (2018) conducted a study entitled "development of human mechanic auotonics S070 interface trainers for electric motor installation learning" which found that: (1) validation of media content by learning media experts, obtained "very feasible categories" (percentage of $89.58 \%$ ); and (2) a learning media trial conducted on 30 students at the Navy Special Vocational School 1 Surabaya, obtaining a "very decent category" with a percentage of $83.04 \%$. A similar study conducted by Eliza, Myori, and Wireksi (2017) with the title "electronic control system trainer" found that: (1) the validation of the media trainer received a score of 0.91 (very high category); and (2) the effectiveness test on the trainers concluded that as many as $89.3 \%$ of students reached the minimum completeness criteria. Another study conducted by Widiantama (2017) with the title "the development of a DC motor speed control system trainer as a learning medium for robotics practice concluded that: (1) the assessment of media experts on trainers, obtained a score of 72 (feasible category); and (2) $50 \%$ of students stated that the trainer was feasible, and as many as $50 \%$ of students stated that the trainer was very appropriate to be used in learning. Furthermore Sarab et al. (2014) in his study entitled "From Traditional Learning into Mobile Learning in Education at the University Level: Undergraduate students' perspective", found that: (1) mobile learning can cover the deficiencies of traditional learning; (2) mobile learning is a substitute for traditional learning systems; and (3) more than half of the students show interest in using cellular learning.

In connection with a number of the results of the above studies, Syarief and Isdianto (2015) conducted a study entitled "analysis of electromagnetic control interference in class IX SMKN 3 Semarang" which found that there were significant differences between student learning outcomes in the experimental class and class control $(\mathrm{t}$ count 2.72> $\mathrm{t}$ table 2.00). Wirawan and Wahyudi (2016) conducted a similar study with the title "Development of electromagnetic trainer visual aids as learning media for basic electrical concepts" which concluded that the scores of student learning outcomes increased from 56.69 to 72.3 in the control class and an increase in scores from 56.11 to 77.44 in the experimental class.

\section{Methodology}

Research with the title "Development of Electric Car Learning Media as an Alternative Car of the Future" was conducted using the ADDIE Model (Brog \& Gall, 2003), with the procedures: Analysis, Design, Development, Implementation \& Evaluation as shown in Fig. 14. 


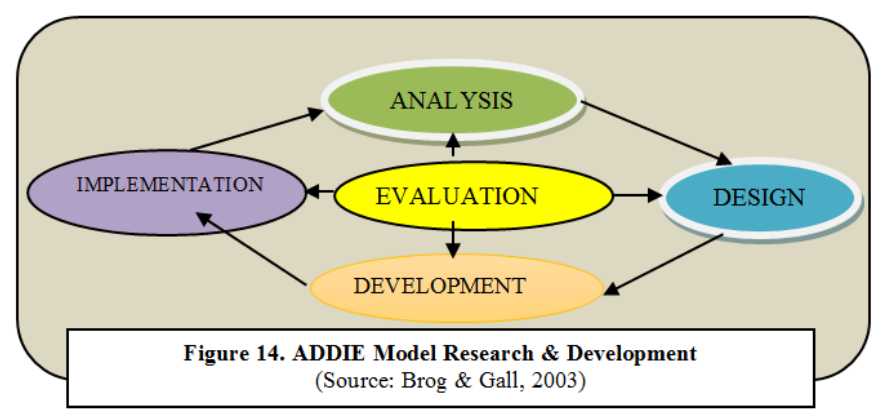

Based on the steps of ADDIE research \& development (Brog \& Gall, 2003) as shown in Figure 14 above, the more detailed research of "Development of Electric Car Learning Media (LMEC) as Alternative Car of the Future" is carried out through the procedure as shown in Fig. 15. The study consisted of 4 steps, namely analysis, design, development, and implementation.

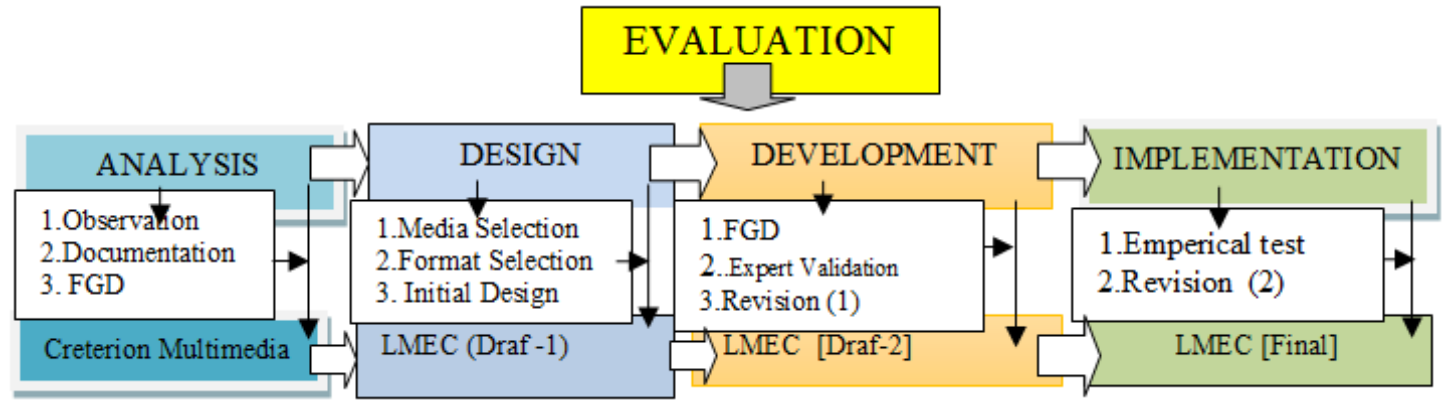

Fig. 15 Development of Electric Car Learning Media as Alternative Cars of the Future (Adaptation of the ADDIE Research \& Development Model) (Source: Brog \& Gall, 2003)

Research procedure:

- Analysis: the first step is a study of learning media through observation of several sources, as well as through questionnaires and focus group discussions (FGD) with instructional media experts and lecturers in the field of electrical engineering, specifically about electric cars. Furthermore, an analysis of the results of the observation, questionnaire, and FGD methods was conducted to obtain the criteria of a learning media about the Electric Car Learning Media (LMEC) as an Alternative Car of the Future;

- Design: based on the learning media criteria as a result of the analysis (first step) mentioned above, then the second step is carried out the "design" activity through (1) media selection; (2) format selection; and (3) initial design. The result of this second step is the "LMEC-1 draft";

- Development: product design in the form of "LMEC-1 Draft" obtained in the second step, then in the third step an FGD activity is carried out. Based on the input obtained in the FGD, the "LMEC-1 Draft" was revised. The next step, Draft LMEC-1, is validated by 3 validators (media experts) so that it becomes "Draft LMEC-2".

- Implementation: "Draft LMEC-2" obtained from the third step, then implemented in the field/class through trials at the Department of Electrical Engineering, State University of Surabaya. Based on the results of the trial, a revision of the deficiencies remaining in the "LMEC-2 Draft" was made, so that it became the final/final product in the form of "LMEC".

Learning media used in teaching and learning activities must be feasible so that it can provide benefits to students. Nieveen (1999) states three aspects that need to be considered in assessing the quality of a product from development research, namely validity, practicality, and effectiveness. In line with this opinion, Seals and Richey (1994) stated that the research product development of instructional media must meet the criteria of validity, practicality, and effectiveness. Furthermore, to determine the level of eligibility of LMEC, the criteria listed in Table 1 below are used with 4 (four) categories, namely: (1) inappropriate; (2) inadequate; (3) good enough; and (4) very feasible.

TABLE I

CATEGORY OF FEASIBILITY BASED ON RATING SCALE

\begin{tabular}{ccl}
\hline No & Score (\%) & \multicolumn{1}{c}{ Eligibility category } \\
\hline 1 & $0 \%-25 \%$ & inappropriate \\
2 & $>25 \%-50 \%$ & inadequate \\
3 & $>50 \%-75 \%$ & enough \\
4 & $>75 \%-100 \%$ & very feasible \\
\hline
\end{tabular}

(Source: Sugiyono, 2010)

\section{RESULTS AND DISCUSSION}

\section{A. Results}

Research result, as explained in the steps in the development of instructional media, that in the third step (development) validation is carried out on the learning media. The results of the validation of the "Electric Car Learning Media Draft (LMEC)" through 3 (three) learning media experts, as shown in Fig. 14.

As shown in Fig. 14, from the aspect of LMEC content, an average score of 92.33 was obtained with a very decent category, while from the aspect of LMEC's appearance, a score of 92.33 (including the very decent category) was obtained. While from the aspect of mobility, practicality, and feasibility of LMEC, each score of 91.33; 91.66; and 90.33, where all three are included in the "very decent" category. 
Based on the evaluation of the three validators, it can be concluded that LMEC is very suitable to be used in the learning process of electric cars in the Department of Electrical Engineering, State University of Surabaya. While the assessment of 31 students (participants of the Electric Car learning) on LMEC is shown in Fig. 15.

Based on Fig. 15, it can be seen that the student's assessment of LMEC can be stated as follows:

- As many as $16(51.61 \%)$ students stated that from the aspect of content, LMEC was very feasible, and the remaining $15(48.38 \%)$ students stated that LMEC was suitable for use in learning;

- As many as $15(48.38 \%)$ students stated that the appearance of LMEC was very feasible, and the remaining $16(51.61 \%)$ students stated that LMEC was suitable for use in learning;
- As many as 18 (58.06\%) students stated that LMEC mobility was very feasible, and the remaining $13(41.93 \%)$ students stated that LMEC was suitable for use in learning

- As many as $17(54.83 \%)$ students stated that the practicality of LMEC was very feasible, and the remaining $14(45.16 \%)$ students stated that LMEC was suitable for use in learning;

- As many as $18(58.06 \%)$ students stated that LMEC was very suitable for use in learning, while the remaining 13 $(41.93 \%)$ students stated that LMEC was suitable for use in learning.

Based on the data in Fig. 15, in general, it can be stated that the Electric Car Learning Media (LMEC) is very feasible to use in learning Electric Cars in the Department of Electrical Engineering, State University of Surabaya. Furthermore, student learning outcomes, as shown in Fig. 16.

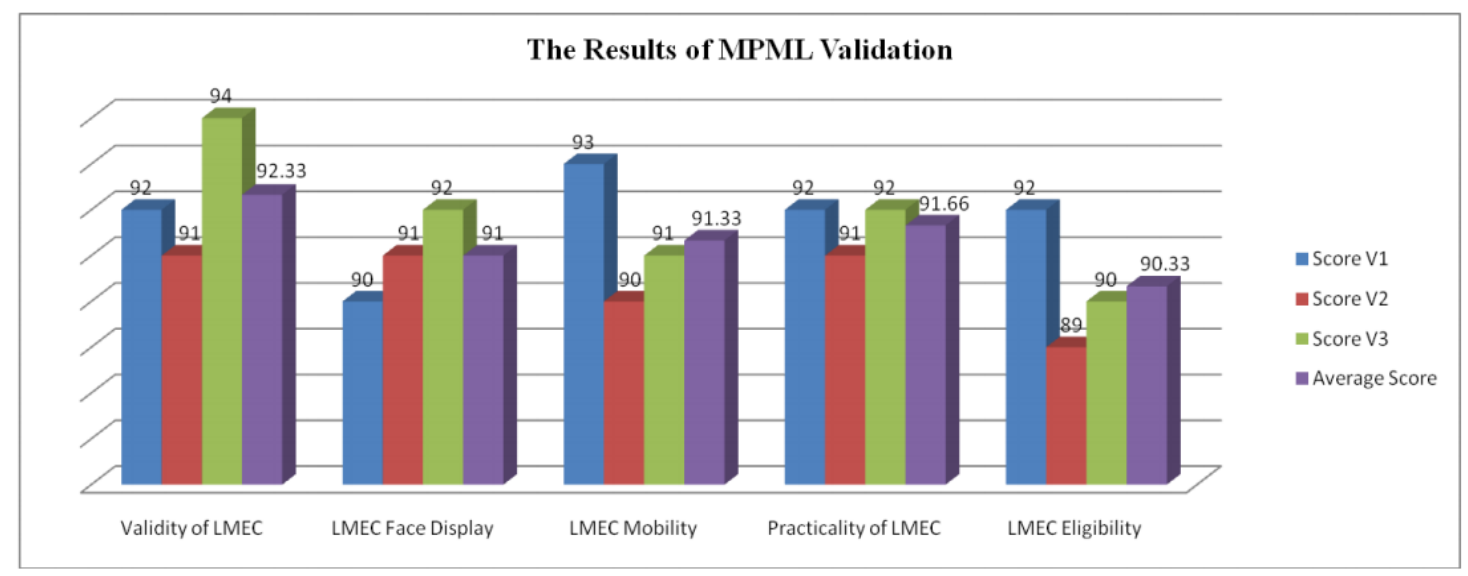

Information: $\mathrm{V}_{1}=$ Validator $1 ; \mathrm{V}_{2}=$ Validator 2 , and $\mathrm{V}_{3}=$ Validator 3

Fig. 14 Bar diagram of the results of LMEC validation by three Media Experts (Validator)

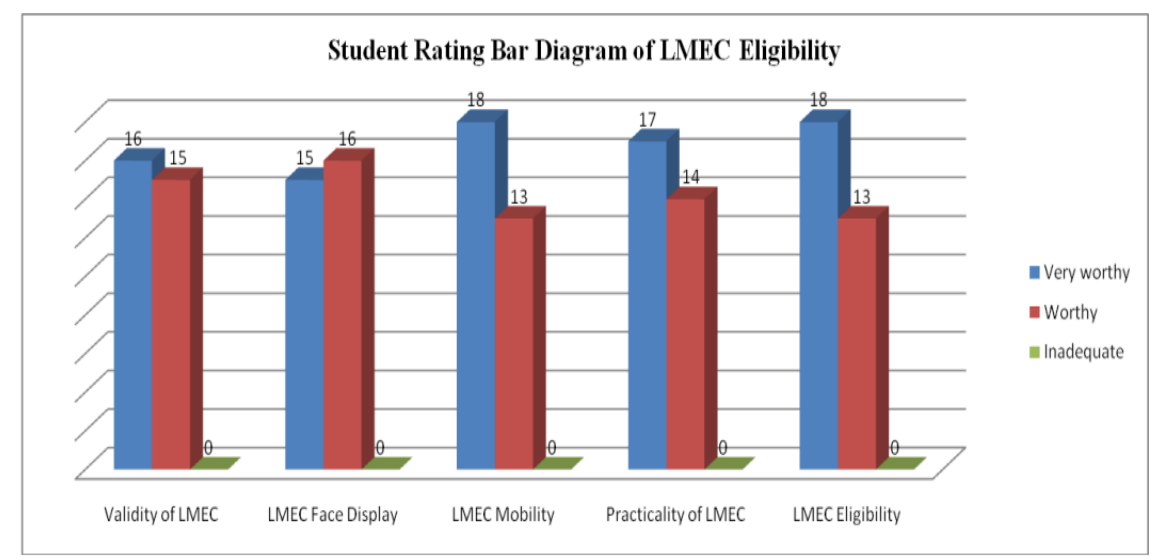

Fig. 15 Student Rating Bar Diagram of LMEC Eligibility 


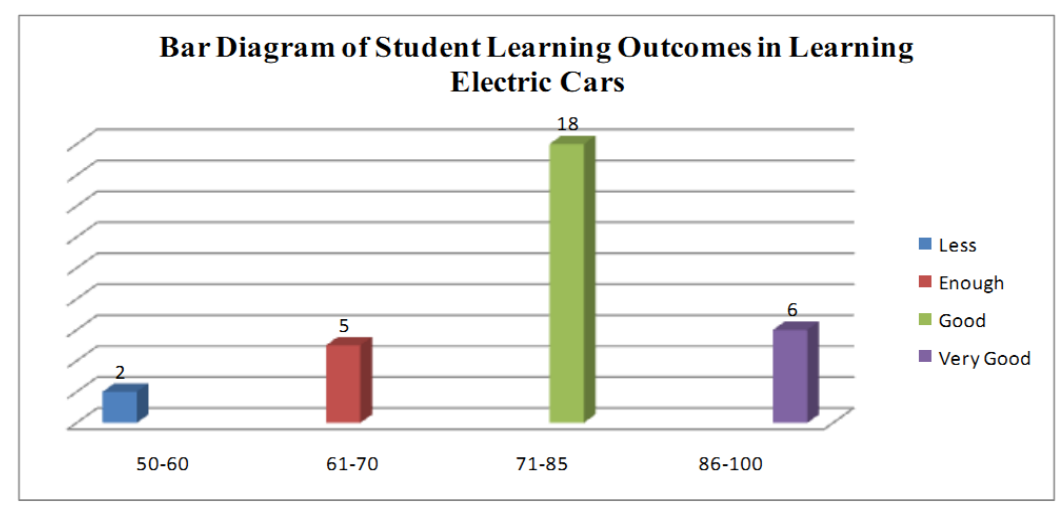

Fig. 16 Bar Diagram of Student Learning Outcomes in Learning Electric Cars

Based on Fig. 16, it can be explained that as many as 2 $(6.45 \%)$ students get a score of learning outcomes in the range of 50-60 with less categories, as many as 5 (16.12\%) students get a score in the range of 61-70 with enough categories, as many as 18 ( 58.06\%) students scored in the range 71-85 in the good category, and the remaining $6(19.35 \%)$ students scored in the range 86-100, in the excellent category. Based on these data, it can be stated that as many as $24(77.41 \%)$ of students obtained scores of learning outcomes in the range of 71-100, with good and excellent categories. Thus it can be concluded that "Electric Car Learning Media (LMEC)" is very effective as a learning medium for Electric Cars in the Department of Electrical Engineering, State University of Surabaya.

\section{B. Discussion}

This research found: (1) based on the validator's assessment, that the Learning Media for Electric Car (LMEC) that has been developed is very feasible to be used in the learning of Electric Cars; (2) based on student assessment, that LMEC is very suitable for use in learning Electric Cars in the Department of Electrical Engineering, State University of Surabaya; and (3) as many as $24(77.41 \%)$ of students obtained learning outcomes in the range of 71-100, with good and excellent categories. The results of this study indicate that LMEC can function properly as a distributor of learning information about Electric Cars. This is in line with the opinion which states that "the media" is a tool that can be used as a vehicle for channeling learning information or channeling messages to achieve learning objectives (Djamarah \& Aswan, 2002). In the context of media as a source of learning, LMEC can be interpreted as a tool/means of communication that allows students to gain knowledge and skills.

With LMEC in the form of audiovisual, the learning of electric cars can be done by demonstration-discussion-practice doing-practice, so that in general students can understand the teaching materials of electric cars, as an alternative to future cars. Thus, the results of this study support the theory of Eyler and Giles (1999), that students can only absorb 5\% of the learning material if the teacher's activities in learning are done with lectures, and if learning is done by reading then the student's absorption increases to by $10 \%$, whereas if learning activities in the form of "doing" include learning with peers, the retention power of students reaches $90 \%$. The results of this study also support the Kemp \& Dayton statement (Ministry of National Education, 2003), that the benefits of learning media are: (1) the delivery of subject matter can be done easily and smoothly; (2) the learning process becomes clearer and more interesting; (3) the learning process becomes more interactive; (4) efficiency in time and energy; (5) improving the quality of student learning outcomes; (6) the media allows the learning process to be carried out anywhere and at any time; (7) the media can foster positive student attitudes towards the material and learning process; and (8) changing the teacher's role in a more positive and productive direction.

The findings of this study are in line with the results of the Eliza, Myori, and Wireksi (2017) research entitled "Electronic control system trainers for learning to operate electronic control systems" which found that: (1) the validation conducted on the Trainer received a score of 0.91 with the category very high; and (2) the effectiveness test of the Trainer states that as many as $89.3 \%$ of students reach the minimum completeness criteria. The results of this study also support the findings of Widiantama (2017) entitled "the development of a DC motor speed control system trainer as a learning medium for robotics practice" which concluded that: (1) the media expert's assessment of the trainer obtained a score of 72 with a decent category; and (2) as many as $50 \%$ of students stated that the trainer was appropriate for use in learning, and the remaining $50 \%$ of students stated that the trainer was very suitable for use in learning the DC motor speed control system.

The findings obtained through this study support the research results of Muslim, Achmad, Budi, Achmad, and Aribowo (2018) written in his research journal entitled "development of human mechanic interface auotonics S070 trainer for electric motor installation learning" which concluded that : (1) validation of media content by learning media experts, obtains a "very feasible category" with a percentage of $89.58 \%$; and (2) by testing the learning media of 30 students at the Special Vocational School 1 Navy, obtained a "very decent category" with a percentage of $83.04 \%$, and it was proven that student learning outcomes improved to reach the "minimum completeness criteria (MCC)". 
As stated above, LMEC is declared to be very feasible and effective in improving student learning outcomes in learning Electric Cars. Thus the results of this study are in line with the findings of Syarief and Isdianto (2015) through their research entitled "application of electromagnetic interference analysis props in subjects operating electromagnetic control systems in class IX SMKN 3 Semarang" which concludes that there are differences insignificant between student learning outcomes in the experimental class and the control class ( $t$ count 2.72 greater than $t$ table 2.00). The results of this study, also support the research results of Wirawan and Wahyudi (2016) with the title "Development of electromagnetic trainer visual aids as learning media for electric basic concepts" which found that in the experimental class and increase in learning outcomes scores was from 56.11 to 77.44 , while in control class an increase in learning outcomes score of 56.69 to 72.3 . This means that the Electromagnetic Trainer "can function well as a learning medium so that student learning outcomes are improved.

\section{CONCLUSIONS}

The study found: (1) based on the validator's assessment, that the LMEC that had been developed was very feasible to be used in learning Electric Cars; (2) based on student assessment, that LMEC is very suitable for use in learning Electric Cars in the Department of Electrical Engineering, State University of Surabaya; and (3) LMEC has proven to be very effective, because as many as $24(77.41 \%)$ of students obtained learning outcomes in the range of 71-100, with good and excellent categories.

\section{REFERENCES}

Akhtar, A.N., \& Ali, R.A. (2012). Use of media for effective its importance: Some consideration. Journal of Elementary Education, 18(1-2), 35-40.

Borg, W.R. \& Gall, M.D. (2003). Educational research an introduction. New York: Longman.

Departemen Pendidikan Nasional (Depdiknas). (2003). Media Pembelajaran. Jakarta: Depdiknas.

Djamarah, Syaiful Bahri \& Aswan Zain. (2002). Strategi Belajar Mengajar, Cetakan Kedua. Jakarta: Rineka Cipta.

Eliza, F., Elvany D., \& Wireksi, G.F. (2017). Trainer sistem kendali elektronik untuk pembelajaran mengoperasikan sistem kendali elektronik. Jurnal Edukasi Elektro. 1(2) November 2017. Universitas Negeri Yogyakarta.

Eyler, J. and Dwight E. Giles, Jr. (1999). Book Review Where's the Learning in Service-Learning?. Michigan Journal of Community Service Learning, Fall 1999, pp. 142-143San Francisco: Jossey-Bass Publishers.

Kemp, J.E. and Dayton, D.K. (1985). Planning and Producing Instructional Media. (Fifth Edition). New York: Harper \& Row, Publishers.

Muslim, S., Achmad, F., Budi. K.S., \& Aribowo, W. (2018). Development of human mechanic interface auotonics SO70 trainer for electric motor installation learning.
Published by Atlantis Press. Article under the CC BY-NC license (https://creative commons.org/ licenses /by-nc/4.0/).

Muslim, S., Suprianto, B., Gitama, N. P. (2018). Development Module (Lab Report) As a Media of Learning in Vocational Education Viewed by Gender. IOP Conference Series: Materials Science and Engineering. ICVEE IOP Publishing IOP Conf. Series: Materials Science and Engineering 336 (2018) 012020 DOI:10.1088/1757899X/336/1/012020.

Nieveen, N. (1999). Prototyping to Reach Product Quality. Jan Van den Akker, Robert Maribe Branch, Ken Gustafson, and Tjeerd Plomp (Ed). London: Kluwer Academic Publishers.

Omadara, O.D., \& Adu, E.I. (2014). The Relevance of educational media and multimedia technology for effective service delivery in teaching and learning processes. IQSR Journal of Research \& Method in Education, 4(2) Ver.1 (Mar-Apr.2014), 48-51.

Preeti. (2014). The education and role of media in education system. International Journal of Scientific Engineering and Research, 2(3), March 2014, 174177.

Sarrab, M., Alzahrani, A., Alwan, N.A., \& Alfarraj, O. (2014). From traditional learning into mobile learning in education at the university level: Undergraduate students' perspective. International Journal of Mobile learning and organization, 8(3-4), 167-186. DOI: 10.1504/ IJMLO.2014.06 7014.

Seals, Barbara B. \& Richey, Rita C. (1994). Teknologi Pembelajaran: Definisi dan Kawasannya. Penerjemah Dewi S. Prawiradilaga dkk. Jakarta: Kerjasama IPTPI LPTK UNJ.

Sudira, P. (2018). TVET Abad XXI: Filosofi, teori, konsep, dan strategi pembelajaran vokasional. Yogyakarta: UNY Press.

Sudira, P. (2018a). Metodologi pembelajaran vokasional abad XXI. Yogyakarta: UNY Press.

Sugiyono. (2011). Metode Penelitian Pendidikan (Pendekatan Kuantitatif, Kualitatif dan $R \& D)$. Bandung: CV. Alfabeta.

Syarief, Ahmad, \& Isdianto. (2015). Aplikasi alat peraga, analisa gangguan pengendali elektromagnitik pada mata pelajaran mengoperasikan sistem pengendali elektromagnitik kelas IX SMKN 3 Semarang. Edu Elektrikal, 4(1). Unversitas Negeri Semarang.

Widiantama, O. (2015). Pengembangan trainer sistem kendali kecepatan motor dc sebagai media pembelajaran praktik robotika. Jurnal Pendidikan Teknik Mekatronika, 7(2), Maret 2017. Universitas Negeri Yogyakarta

Wirawan, B.Y. dan Wahyudi. (2016). Pengembangan peraga trainer elektromagnetik sebagai media pembelajaran konsep kelistrikan dasar. Jurnal Pendidikan Teknik Mesin, 16(1). Universitas Negeri Semarang. 